\title{
Pro-inflammatory diet, frailty and sarcopenia: a study with older people in
}

\section{outpatient care}

\author{
Dieta pró- inflamatória, fragilidade e sarcopenia: um estudo com pessoas idosas em assistência \\ ambulatorial \\ Dieta proinflamatoria, fragilidad y sarcopenia: un estudio con ancianos en atención ambulatoria
}

Gabriela Benatti de Oliveira

ORCID: https://orcid.org/0000-0003-0327-6646 Federal University of Alfenas, Brazil

E-mail: gabi.benatti.11@gmail.com

Cintia Midori Yogi

ORCID: https://orcid.org/0000-0002-6992-0476 Federal University of Alfenas, Brazil E-mail: midori_cintia@hotmail.com

Fernanda de Carvalho Vidigal

ORCID: https://orcid.org/0000-0001-8187-0603 Federal University of Alfenas, Brazil E-mail: fcvidigal@gmail.com

Daniela Braga Lima

ORCID: https://orcid.org/0000-0002-6755-9744 Federal University of Alfenas, Brazil E-mail: danibraga6@gmail.com

Alice Helena de Souza Paulino

ORCID: https://orcid.org/0000-0003-3906-8259 Faculty of São Lourenço, Brazil E-mail: alicehpaulino@gmail.com

Tábatta Renata Pereira de Brito ORCID: https://orcid.org/0000-0001-9466-2993 Federal University of Alfenas, Brazil E-mail: tabatta.brito@unifal-mg.edu.br

\begin{abstract}
Objectives: To analyze the relationship between the Dietary Inflammatory Index (DII), sarcopenia, and frailty syndrome in older people. Methods: A cross-sectional, non-probabilistic study was carried out with 135 older people, attended by a general outpatient clinic. The older people were classified in relation to sarcopenia according to the European Working Group on Sarcopenia in Older People. The frailty classification was made through self-referred questions. The calculation of the DII was made using the iOS application IF RATING®. Association analysis was performed using multiple logistic regression. Results: Of the 135 older people evaluated, $17.78 \%$ were classified as sarcopenic and $47.41 \%$ as frail. No association was observed between the most inflammatory DII and sarcopenia. Regarding frailty syndrome, older people with a more inflammatory DII were more likely to be frail $(O R=3.64$; 95\% CI=1.24-10.70). Discussion: These results could stimulate actions to promote an anti-inflammatory diet, with a view to preventing frailty in older people.
\end{abstract}

Keywords: Inflammation; Sarcopenia; Frailty.

\section{Resumo}

Objetivos: Analisar a relação entre o Índice Inflamatório Dietético (IID), a sarcopenia e a síndrome da fragilidade em idosos.Métodos: Estudo transversal, não probabilístico, realizado com 135 idosos atendidos em ambulatório geral. Os idosos foram classificados em relação à sarcopenia de acordo com o Grupo de Trabalho Europeu sobre Sarcopenia em Pessoas Idosas. A classificação da fragilidade foi feita por meio de questões autorreferidas. O cálculo do IID foi feito por meio do aplicativo iOS IF RATING®. A análise de associação foi realizada por meio de regressão logística múltipla.Resultados: Dos 135 idosos avaliados, 17,78\% foram classificados como sarcopênicos e 47,41\% como frágeis. Não foi observada associação entre o IID mais inflamatório e a sarcopenia. Em relação à síndrome da fragilidade, idosos com IID mais inflamatório apresentaram maior probabilidade de serem frágeis $(\mathrm{OR}=3,64$; IC95\% = 1,24-10,70). Discussão: Esses resultados podem estimular ações de promoção de dieta antiinflamatória, com vistas à prevenção da fragilidade em idosos.

Palavras-chave: Inflamação; Sarcopenia; Fragilidade. 


\begin{abstract}
Resumen
Objetivos: Analizar la relación entre el Índice Inflamatorio Alimentario (IIA), la sarcopenia y el síndrome de fragilidad en personas mayores. Métodos: se realizó un estudio transversal, no probabilístico, con 135 ancianos, atendidos por un ambulatorio general. Las personas mayores se clasificaron en relación con la sarcopenia según el Grupo de Trabajo Europeo sobre Sarcopenia en Personas Mayores. La clasificación de la fragilidad se realizó mediante preguntas autoreferidas. El cálculo del IIA se realizó mediante la aplicación de iOS IF RATING®. El análisis de asociación se realizó mediante regresión logística múltiple. Resultados: De las 135 personas mayores evaluadas, el 17,78\% se clasificaron como sarcopénicas y el 47,41\% como frágiles. No se observó asociación entre la IIA más inflamatoria y la sarcopenia. Con respecto al síndrome de fragilidad, las personas mayores con un IIAA más inflamatorio tenían más probabilidades de ser frágiles $(\mathrm{OR}=3,64$; IC del 95\% = 1,24-10,70). Discusión: Estos resultados podrían estimular acciones para promover una dieta antiinflamatoria, con miras a prevenir la fragilidad en las personas mayores.
\end{abstract}

Palabras clave: Inflamación; Sarcopenia; Fragilidad.

\title{
1. Introduction
}

Appropriate diagnostic and therapeutic approaches for older people are essential in outpatient care to prevent the first care from occurring at an advanced stage, in the hospital, increasing costs and decreasing the chances of a favorable prognosis.

Among the conditions that affect the older people and require outpatient care, there is sarcopenia, as it is a physiological alteration resulting from the aging process which requires attention due to the harmful consequences associated with it. The updated definition of sarcopenia by the European Working Group on Sarcopenia in Older People (EWGSOP) considers that sarcopenia is a progressive and generalized skeletal muscle disorder characterized by low levels of muscle strength, muscle quantity/quality, and physical performance as an indicator of severity (Cruz-Jentoft et al., 2019).

As a deleterious consequence to the health of older people, sarcopenia is associated with an increased likelihood of adverse outcomes, including falls, fractures, physical disability, and mortality (Cruz-Jentoft et al., 2019).

Frailty syndrome, on the other hand, is characterized by the reduction in energy reserve and physiological resistance, resulting in the cumulative decline of organs and body systems and, consequently, in neuromuscular alterations and immune system dysfunction that interfere in the inflammatory process and disrupt the endocrine system. Thus, like sarcopenia, frailty is considered an important public health issue, as it increases the occurrence of falls, disability, hospitalization, and death (Rossi et al., 2021).

Despite being different conditions (sarcopenia is a disease that contributes to the development of physical frailty and frailty is a geriatric syndrome that represents a broader concept), the inflammatory process is present in both as a mechanism involved in the genesis and evolution. This is because aging is associated with a significant increase in serum levels of inflammatory markers and their related factors, which characterizes a state of chronic low-grade inflammation denominated “inflammaging”. Inflammaging can result in responses that lead to tissue degeneration, and acute inflammatory responses may be impaired with aging, leading to an increased susceptibility to infection (Teskey et al., 2019).

Thus, considering the significant increase in older people in the population, the epidemiological magnitude of frailty and sarcopenia among these individuals, and that studies on this topic are scarce and restricted to older residents in the community, the present study aims to analyze the association between DII (Dietary Inflammatory Index) and frailty and between DII and sarcopenia in older people in outpatient care.

\section{Methodology}

\subsection{Subjects and study design}

A cross-sectional, non-probabilistic study was carried out with 135 individuals aged 60 years or older, attended by a general outpatient clinic in a municipality located in the southeastern region of Brazil (Polit \& Beck, 2011). The sample size was calculated using the Open Epi Program, version 3.01 considering a prevalence of sarcopenia and frailty of $15 \%, \alpha=0.05$, 
and $\beta=0.8$. The study included all older people who attended the Outpatient Clinic on Mondays, Tuesdays, and Fridays, between the months of May and September 2018 and who agreed to participate in the study.

Considering that this is a study involving human beings, the fundamental ethical principles established for scientific research were followed, and the project was approved by the Research Ethics Committee of the Federal University of Alfenas, Brazil (Opinion n ${ }^{\circ} 2.595 .551$ on 12/04/2018).

The inclusion criteria were aged 60 years or older and resident in the urban area. The exclusion criteria were: presenting mobility problems that made the tests unfeasible and/or presenting neurological and cognitive conditions that made it impossible for the older adult to answer the questionnaires.

Data collection was carried out in the outpatient clinic, in individual consultations, in two stages. In the first stage, a personal interview, anthropometric assessment, and 24-hour recall were performed. Subsequently, in the second stage, two 24hour recalls were completed via telephone. The two additional recalls were completed within seven days after the interview, on alternate days, in order to guarantee two typical days and an atypical day.

\subsection{Measurements}

\subsubsection{Dietary Inflammatory Index (DII)}

To evaluate the DII, the iOS IF RATING® application was used. The application algorithm to calculate the inflammatory factor includes more than 20 different factors that affect the inflammatory or anti-inflammatory potential of a food, including: structure and type of lipid, essential fatty acids, vitamins, minerals and antioxidants, glycemic index, and antiinflammatory compounds. For each of these factors, the points are added or subtracted based on the quantity of this nutrient present compared to its effects seen at various dosages on inflammation in humans. The result is a single number that estimates the effects of all of these factors (Reinagel, 2007). The nutrients mainly derived from fruits and vegetables as well as n-3 fatty acids, fiber, antioxidants, vitamin D and probiotics are the main anti-inflammatory components in the DII score. The foods often mentioned in this context include fish, fermented dairy products, fruits and vegetables, whole grain, and spices (e.g., ginger, turmeric) (Pimentel et al., 2016; Vadell et al., 2020). A negative DII value suggests that a food or meal can have inflammatory effects, while positive values indicate an anti-inflammatory effect. The higher the number, the stronger the effect in both cases (Reinagel, 2007). The distribution of the DII into quintiles was adopted. Thus, older people with DII in the first quintile, that is, among the $20 \%$ of the sample with the lowest index, were classified as "more inflammatory DII" and older people in the second, third, fourth, and fifth quintiles were grouped in the "less inflammatory DII" category.

\subsubsection{Sarcopenia}

Sarcopenia was defined according to the European Consensus, published in 2019 by EWGSOP (Cruz-Jentoft et al., 2019). Older individuals with low muscle strength measured in kilogram-strength (Kgf) were considered as having sarcopenia - the mean of three measurements obtained using a manual dynamometer was used, being considered positive if less than 16 Kgf in women and less than $27 \mathrm{Kgf}$ in men - associated with low muscle quantity and quality estimated by Lee's equation. This equation was validated for the Brazilian population and uses the following variables: height (meters), weight ( $\mathrm{kg}$ ), sex, age, and ethnicity, being: Appendicular Skeletal Muscle Mass $($ ASMM) $=0.244$ x Weight +7.8 x Height +6.6 x Sex -0.098 x Age + Ethnicity - 3.3. Regarding the sex variable, 0 should be used for men and 1 for women; in relation to ethnicity, -1.2 is used for Asian people, 1.4 for black people, and 0 for white people (Lee et al., 2000). The cutoff of ASMM used in the present study was based on the $20 \%$ lowest percentile of the population distribution, representing $6,58 \mathrm{~kg} / \mathrm{m} 2$ for women and $9,28 \mathrm{~kg} / \mathrm{m} 2$ for men. (Delmonico et al., 2007; Newman et al., 2003) 


\subsubsection{Frailty}

A self-reported frailty questionnaire was used, containing questions related to the components of this syndrome (Nunes et al., 2015). Older people who scored positively for three or more components were considered "frail" and those who scored positively for two or less components "non-frail".

\subsubsection{Covariables}

Socio-demographic characteristics: age (years); sex (female and male); family income (reais); education (number of years that the older adult attended school); and living arrangements, grouped based on co-residence between generations as follows; living alone; living only with a spouse; living with children and no grandchildren (with or without the presence of a spouse and/or sons in law/daughters in law); living with children and grandchildren (with or without the presence of a spouse and/or sons in law/daughters in law); other arrangements composed of relatives or non-relatives.

Health status. Multimorbidity (yes - two or more diseases / no - zero or one disease). Polypharmacy (yes - five or more medicines / no - four or less medicines). Disability was assessed using the modified version of the Katz Activity of Daily Living scale (ADLs) (Katz et al., 1963) and the Lawton Instrumental Activities of Daily Living scale (IADLs) (Lawton \& Brody, 1969). Older people who reported difficulty in at least one activity were considered as having a dependency. Cognitive status was assessed using the Mini Mental State exam (MMSE) (Folstein et al., 1975). Previously published cut-offs were used for different levels of formal education (Brucki et al., 2003). Depressive symptoms were assessed using the geriatric depression scale (Yesavage \& Sheikh, 1986). Body mass index (BMI) was classified as ideal (22 - $27 \mathrm{~kg} / \mathrm{m} 2)$, underweight (<22 kg/m2), or overweight (>27 kg/m2) (Lipschitz, 1994).

\subsection{Data analysis}

The data were analyzed using Stata software, version 13.0. In the descriptive analysis of the data, frequency distributions, means and standard deviations were estimated for the continuous variables of the study. For categorical variables, proportions were estimated. Differences between groups were estimated using Pearson's $\chi^{2}$ test. For continuous variables, differences between groups were assessed using the Mann-Whitney test. In all analyzes, a significance level of 5\% was used. Association analysis was performed using multiple logistic regression. The magnitude of the association was estimated by the crude and adjusted odds ratio (OR). Variables that, according to the literature, are associated with outcomes were included in the model for adjustment (depressive symptoms, cognitive performance, functional capacity, years of schooling, and age).

\section{Results}

Of the 135 older people evaluated, $57.04 \%$ were female and the mean age of the sample was 70.33 years $(\mathrm{SD}=7.1)$. The mean family income was $\mathrm{R}$ 2,974.97 (the minimum wage in Brazil in 2018 was $\mathrm{R} \$ 954.00$ ), with more than half of the older people living alone or only with their spouse (52.59\%). The mean number of years of schooling was 6.7 years $(\mathrm{SD}=4.7)$ and, regarding marital status, $65.19 \%$ of the older people have a partner. With regard to aspects related to health, $71.85 \%$ of the older people reported two or more chronic diseases, $54.07 \%$ were overweight, and $31.11 \%$ said they used five or more medications per day, characterizing polypharmacy. With respect to cognition, $60.74 \%$ were above the cut-off score in the MMSE and the mean of depressive symptoms reported by the GDS was 3.70. The majority of the older participants were independent for ABVD (86.67\%) and IADL (69.63\%) (Table 1).

The mean DII of the sample was -489.01 ( $\mathrm{SD}=309.3$ ). The older people with the highest DII, characterizing the diet with the highest anti-inflammatory content, obtained an index of 306.52, while those with the lowest DII obtained an index of - 
1856.13, which characterizes a strongly inflammatory diet. It should be noted that $50 \%$ of the sample presented a DII equal to or less than -463.61 . When analyzing the distribution by quintiles, it was observed that in the first quintile, that is, among the $20 \%$ of the sample with the lowest DII, the index values varied between -1856.13 and -639.85 . In the final quintile, that is, among the $20 \%$ with the highest DII, the values were between -285.69 and 306.32 , with only three older people presenting positive values.

As can be seen in Table 1, a statistically significant difference was found in the proportions of older people with a less inflammatory and more inflammatory DII, only with regard to BADL, where the proportion of dependent older people was higher among those with a more inflammatory DII.

Table 1 - Distribution of the older people according to sociodemographic and health characteristics and the Dietary Inflammatory Index. Alfenas, 2018.

\begin{tabular}{|c|c|c|c|c|c|}
\hline \multirow[t]{2}{*}{ Variable } & \multirow[t]{2}{*}{ Categories } & \multirow{2}{*}{$\begin{array}{l}\text { Total } \\
\mathrm{n}(\%)\end{array}$} & \multicolumn{2}{|c|}{ Dietary Inflammatory Index } & \multirow[t]{2}{*}{$p$} \\
\hline & & & $\begin{array}{l}\text { Less inflammatory } \\
\mathrm{n}(\%)\end{array}$ & $\begin{array}{l}\text { More } \\
\text { inflammatory } \\
\mathrm{n}(\%)\end{array}$ & \\
\hline \multirow[t]{2}{*}{ Sex } & Feminine & $77(57.04)$ & $61(56.48)$ & $16(59.26)$ & 0.794 \\
\hline & Masculine & $58(42.96)$ & $47(43.52)$ & $11(40.74)$ & \\
\hline Age* & & $70.33(7.1)$ & $70.40(7.2)$ & $70.07(6.6)$ & 0.905 \\
\hline Years of schooling* & & $6.70(4.7)$ & $6.56(4.6)$ & $7.26(5.1)$ & 0.481 \\
\hline Family income* & & $\begin{array}{l}2974.97 \\
(3706.07)\end{array}$ & $\begin{array}{l}3110.53 \\
(3920.17)\end{array}$ & $\begin{array}{l}2432.70 \\
(2676.17)\end{array}$ & 0.376 \\
\hline \multirow[t]{2}{*}{ Marital status } & With partner & $88(65.19)$ & $69(63.89)$ & $19(70.37)$ & 0.527 \\
\hline & Without partner & $47(34.81)$ & $39(36.11)$ & $8(29.63)$ & \\
\hline \multirow[t]{5}{*}{ Family arrangement } & Live alone & $20(14.81)$ & $16(14.81)$ & $4(14.81)$ & 0.994 \\
\hline & $\begin{array}{l}\text { Live only with } \\
\text { spouse }\end{array}$ & $51(37.78)$ & $41(37.96)$ & $10(37.04)$ & \\
\hline & Live with children & $27(20.00)$ & $22(20.37)$ & $5(18.52)$ & \\
\hline & $\begin{array}{ll}\text { Live } & \text { with } \\
\text { grandchildren }\end{array}$ & $25(18.52)$ & $20(18.52)$ & $5(18.52)$ & \\
\hline & Others & $12(8.89)$ & $9(8.33)$ & $3(11.11)$ & \\
\hline \multirow[t]{2}{*}{ MMSE } & No alteration & $82(60.74)$ & $64(59.26)$ & $18(66.67)$ & 0.491 \\
\hline & With alteration & & $44(40.74)$ & $9(33.33)$ & \\
\hline GDS* & & $3.70(2.5)$ & $3.78(2.5)$ & $3.37(2.8)$ & 0.280 \\
\hline \multirow[t]{2}{*}{ Multimorbidity } & No & $38(28.15)$ & $29(26.85)$ & $9(33.33)$ & 0.503 \\
\hline & Yes & $97(71.85)$ & $79(73.15)$ & $18(66.67)$ & \\
\hline \multirow[t]{2}{*}{ Polypharmacy } & No & $93(68.89)$ & $74(68.52)$ & $19(70.37)$ & 0.853 \\
\hline & Yes & $42(31.11)$ & $34(31.48)$ & $8(29.63)$ & \\
\hline
\end{tabular}




\begin{tabular}{llllll} 
IADL & Independent & $94(69.63)$ & $75(69.44)$ & $19(70.37)$ & 0.925 \\
& Dependent & $41(30.37)$ & $33(30.56)$ & $8(29.63)$ & \\
BADL & Independent & $117(86.67)$ & $98(90.74)$ & $19(70.37)$ & 0.005 \\
& Dependent & $18(13.33)$ & $10(9.26)$ & $8(29.63)$ & 0.922 \\
BMI & Underweight & $17(12.59)$ & $13(12.04)$ & $4(14.81)$ & $9(33.33)$ \\
& Eutrophic & $45(33.33)$ & $36(33.33)$ & $14(51.85)$ & \\
\hline
\end{tabular}

Note: The difference is significant at $\mathrm{p}<0.05$. MMSE - Mini Mental State Examination; GDS - Geriatric Depression Scale; IADL - Instrumental Activity of Daily Living; BADL - Basic Activity of Daily Living; BMI - Body Mass Index; *mean (standard deviation). Source: Authors (2021).

The prevalences of sarcopenia and frailty syndrome were $17.78 \%$ and $47.41 \%$, respectively. Although no statistically significant differences were found between frailty syndrome, sarcopenia, and DII, higher proportions of older people who reported weight loss, muscle weakness, reduced walking speed, fatigue, and a low level of physical activity were observed among those with a more inflammatory DII. The same is true among the older people classified as sarcopenic and, more specifically, those with low handgrip strength and low skeletal appendicular mass (TABLE 2).

Table 2 - Distribution of the older people according to frailty syndrome, sarcopenia, and the Dietary Inflammatory Index. Alfenas, 2018.

\begin{tabular}{|c|c|c|c|c|}
\hline \multirow[b]{2}{*}{ Variable } & \multirow[b]{2}{*}{ Categories } & \multicolumn{2}{|c|}{ Dietary Inflammatory Index } & \multirow[b]{2}{*}{$p$} \\
\hline & & $\begin{array}{l}\text { Less inflammatory } \\
\mathrm{n}(\%)\end{array}$ & $\begin{array}{l}\text { More } \\
\text { inflammatory } \\
\mathrm{n}(\%)\end{array}$ & \\
\hline \multirow[t]{2}{*}{ Frailty Syndrome } & Non-frail & $61(56.48)$ & $10(59.26)$ & 0.070 \\
\hline & Frail & $47(43.52)$ & $17(40.74)$ & \\
\hline \multirow[t]{2}{*}{ Loss of weight } & No & $83(76.85)$ & $19(70.35)$ & 0.483 \\
\hline & Yes & $25(23.15)$ & $8(29.63)$ & \\
\hline \multirow[t]{2}{*}{ Muscle weakness } & No & $46(42.59)$ & $11(40.74)$ & 0.862 \\
\hline & Yes & $62(57.41)$ & $16(59.26)$ & \\
\hline \multirow[t]{2}{*}{ Reduced walking speed } & No & 42(38.89) & $6(22.22)$ & 0.106 \\
\hline & Yes & $66(61.11)$ & $21(71.78)$ & \\
\hline \multirow[t]{2}{*}{ Fatigue } & No & $86(79.63)$ & $20(74.07)$ & 0.530 \\
\hline & Yes & $22(20.37)$ & $7(25.93)$ & \\
\hline \multirow[t]{2}{*}{ Low level of physical activity } & No & $42(38.89)$ & $9(33.33)$ & 0.594 \\
\hline & Yes & $66(61.11)$ & $18(66.67)$ & \\
\hline \multirow[t]{2}{*}{ Sarcopenia } & No & $90(83.33)$ & $21(77.78)$ & 0.499 \\
\hline & Yes & $18(16.67)$ & $6(22.22)$ & \\
\hline \multirow[t]{2}{*}{ Low handgrip strength } & No & $82(75.93)$ & $20(74.07)$ & 0.841 \\
\hline & Yes & $26(24.07)$ & $7(25.93)$ & \\
\hline \multirow[t]{2}{*}{ Low skeletal appendicular mass } & No & $89(82.41)$ & $20(74.07)$ & 0.326 \\
\hline & Yes & $19(17.59)$ & $7(25.93)$ & \\
\hline
\end{tabular}

Note: The difference is significant at $\mathrm{p}<0.05$. Source: Authors (2021).

Analyzing the relationship between sociodemographic and health characteristics, and frailty syndrome, there was a statistically significant difference with regard to years of schooling, family income, depressive symptoms, and BADL, with the mean of depressive symptoms being higher among frail participants, the mean number of years of schooling and income being higher among the non-frail, and the proportion of older people dependent for BADLs being higher among the frail (Table 3). 
Research, Society and Development, v. 10, n. 17, e103101724488, 2021

(CC BY 4.0) | ISSN 2525-3409 | DOI: http://dx.doi.org/10.33448/rsd-v10i17.24488

Table 3 - Distribution of the older people according to the sociodemographic and health characteristics, and frailty syndrome.

Alfenas, 2018.

\begin{tabular}{|c|c|c|c|c|}
\hline Variable & Categories & $\begin{array}{l}\text { Frailty Syn } \\
\text { Non-frail } \\
\mathrm{n}(\%)\end{array}$ & $\begin{array}{l}\text { Frail } \\
\mathrm{n}(\%)\end{array}$ & $p$ \\
\hline \multirow[t]{2}{*}{ Sex } & Feminine & $37(52.11)$ & $40(62.50)$ & \multirow[t]{2}{*}{0.22} \\
\hline & Masculine & $34(47.89)$ & $24(37.50$ & \\
\hline Age* $^{*}$ & & $70.11(6.5)$ & $70.57(7.7)$ & 0.945 \\
\hline Years of schooling* & & $7.59(4.6)$ & $5.71(4.6)$ & 0.008 \\
\hline \multirow{2}{*}{ Family income* } & & 3374.53 & 2531.70 & \multirow[t]{2}{*}{0.014} \\
\hline & & $(4272.7)$ & $(2923.9)$ & \\
\hline \multirow[t]{2}{*}{ Marital status } & With partner & $48(67.61)$ & $40(62.50)$ & \multirow[t]{2}{*}{0.534} \\
\hline & Without partner & $23(32.39)$ & $24(37.50)$ & \\
\hline \multirow[t]{5}{*}{ Family arrangement } & Live alone & $6(8.45)$ & $14(21.88)$ & \multirow[t]{5}{*}{0.14} \\
\hline & Live only with spouse & $32(45.07)$ & $19(29.69)$ & \\
\hline & Live with children & $15(21.13)$ & $12(18.75)$ & \\
\hline & Live with grandchildren & $13(18.31)$ & $12(18.75)$ & \\
\hline & Others & $5(7.04)$ & $7(10.94)$ & \\
\hline \multirow[t]{2}{*}{ MMSE } & No alteration & $48(67.61)$ & $34(53.13)$ & \multirow[t]{2}{*}{0.085} \\
\hline & With alteration & $23(32.39)$ & $30(46.88)$ & \\
\hline GDS* & & $2.59(2.1)$ & $4.93(2.4)$ & 0.000 \\
\hline \multirow[t]{2}{*}{ Multimorbidity } & No & $23(32.39)$ & $15(23.44)$ & \multirow[t]{2}{*}{0.248} \\
\hline & Yes & $48(67.61)$ & $49(76.56)$ & \\
\hline \multirow[t]{2}{*}{ Polypharmacy } & No & $53(74.65)$ & $40(62.50)$ & \multirow[t]{2}{*}{0.128} \\
\hline & Yes & $18(25.35)$ & $24(37.50)$ & \\
\hline \multirow[t]{2}{*}{ IADL } & Independent & $54(76.06)$ & $40(62.50)$ & \multirow[t]{2}{*}{$0.08^{\prime}$} \\
\hline & Dependent & $17(23.94)$ & $24(37.50)$ & \\
\hline \multirow[t]{2}{*}{ BADL } & Independent & $67(94.37)$ & $50(78.13)$ & \multirow[t]{2}{*}{0.00} \\
\hline & Dependent & $4(5.63)$ & $14(21.88)$ & \\
\hline \multirow[t]{3}{*}{ BMI } & Underweight & $7(9.86)$ & $10(15.63)$ & \multirow[t]{3}{*}{0.594} \\
\hline & Eutrophic & $24(33.80)$ & $21(32.81)$ & \\
\hline & Overweight & $40(56.34)$ & $33(51.56)$ & \\
\hline \multirow[t]{2}{*}{ DII } & Less inflammatory & $61(85.92)$ & $47(73.44)$ & \multirow[t]{2}{*}{0.070} \\
\hline & More inflammatory & $10(14.08)$ & $17(26.56)$ & \\
\hline
\end{tabular}

Note: The difference is significant at $\mathrm{p}<0.05$. MMSE - Mini Mental State Examination; GDS - Geriatric Depression Scale; IADL - Instrumental Activity of Daily Living; BADL - Basic Activity of Daily Living; BMI - Body Mass Index; DII - Dietary Inflammatory Index; *mean (standard deviation). Source: Authors. 
Table 4 - Distribution of the older people according to sociodemographic and health characteristics, and sarcopenia. Alfenas, 2018.

\begin{tabular}{|c|c|c|c|c|}
\hline Variable & Categories & $\begin{array}{l}\text { Sarcopenia } \\
\text { No } \\
\mathrm{n}(\%)\end{array}$ & $\begin{array}{l}\text { Yes } \\
\mathrm{n}(\%)\end{array}$ & $p$ \\
\hline \multirow[t]{2}{*}{ Sex } & Feminine & $64(57.66)$ & $13(54.17)$ & \multirow[t]{2}{*}{0.754} \\
\hline & Masculine & $47(42.34)$ & $11(45.83)$ & \\
\hline Age* & & $69.89(6.9)$ & $72.37(7.2)$ & 0.108 \\
\hline Years of schooling* & & $6.67(4.5)$ & $6.83(5.4)$ & 0.859 \\
\hline Family income* & & $\begin{array}{l}3126.40 \\
(4039.6)\end{array}$ & $\begin{array}{l}2274.58 \\
(1162.39)\end{array}$ & 0.869 \\
\hline \multirow[t]{2}{*}{ Marital status } & With partner & $78(70.27)$ & $10(41.67)$ & \multirow[t]{2}{*}{0.008} \\
\hline & Without partner & $33(29.73)$ & $14(58.33)$ & \\
\hline \multirow[t]{5}{*}{ Family arrangement } & Live alone & $14(12.61)$ & $6(25.00)$ & \multirow[t]{5}{*}{0.327} \\
\hline & Live only with spouse & $45(40.54)$ & $6(25.00)$ & \\
\hline & Live with children & $22(19.82)$ & $5(20.83)$ & \\
\hline & Live with grandchildren & $19(17.12)$ & $6(25.00)$ & \\
\hline & Others & $11(9.91)$ & $1(4.17)$ & \\
\hline \multirow[t]{2}{*}{ MMSE } & No alteration & $74(66.67)$ & $8(33.33)$ & \multirow[t]{2}{*}{0.003} \\
\hline & With alteration & $37(33.33)$ & $16(66.67)$ & \\
\hline GDS & & $3.54(2.6)$ & $4.41(2.1)$ & 0.051 \\
\hline \multirow[t]{2}{*}{ Multimorbidity } & No & $30(27.03)$ & $8(33.33)$ & \multirow[t]{2}{*}{0.347} \\
\hline & Yes & $81(72.97)$ & $16(66.67)$ & \\
\hline \multirow[t]{2}{*}{ Polypharmacy } & No & $74(66.67)$ & $19(79.17)$ & \multirow[t]{2}{*}{0.170} \\
\hline & Yes & $37(33.33)$ & $5(20.83)$ & \\
\hline \multirow[t]{2}{*}{ IADL } & Independent & $77(69.37)$ & $17(70.83)$ & \multirow[t]{2}{*}{0.888} \\
\hline & Dependent & $34(30.63)$ & $7(29.17)$ & \\
\hline \multirow[t]{2}{*}{ BADL } & Independent & $95(85.59)$ & $22(91.67)$ & \multirow[t]{2}{*}{0.339} \\
\hline & Dependent & $16(14.41)$ & $2(8.33)$ & \\
\hline \multirow[t]{3}{*}{ BMI } & Underweight & $2(1.80)$ & $15(62.50)$ & \multirow[t]{3}{*}{0.000} \\
\hline & Eutrophic & $36(32.43)$ & $9(37.50)$ & \\
\hline & Overweight & $73(65.77)$ & $0(0.00)$ & \\
\hline \multirow[t]{2}{*}{ DII } & Less inflammatory & $90(81.08)$ & $18(75.00)$ & \multirow[t]{2}{*}{0.499} \\
\hline & More inflammatory & $21(18.92)$ & $6(25.00)$ & \\
\hline
\end{tabular}

Note: The difference is significant at $\mathrm{p}<0.05$. MMSE - Mini Mental State Examination; GDS - Geriatric Depression Scale; IADL - Instrumental Activity of Daily Living; BADL - Basic Activity of Daily Living; BMI - Body Mass Index; DII - Dietary Inflammatory Index; *mean (standard deviation). Source: Authors (2021).

Two multiple logistic regression models were constructed; the first for sarcopenia and the second for frailty syndrome. No association was found between a more inflammatory DII and sarcopenia. Regarding the association between a more inflammatory DII and frailty syndrome, Table 5 shows that older people with a more inflammatory DII are 2.64 times more likely to be frail than older people with a less inflammatory DII in the model adjusted for depressive symptoms, cognitive performance, functional capacity, years of schooling, and age. 
Table 5 - Factors associated with Frailty Syndrome. Alfenas, 2018.

\begin{tabular}{lll}
\hline & OR $_{\text {Cude }}(95 \% \mathrm{CI})$ & OR $_{\text {adjusted }}(95 \% \mathrm{CI})$ \\
\hline Dietary Inflammatory Index & & 1.00 \\
$\quad$ Less inflammatory & 1.00 & $3.64(1.24-10.70)$ \\
$\quad$ More inflammatory & $2.20(0.92-5.26)$ & $1.58(1.29-1.93)$ \\
GDS & $1.57(1.30-1.89)$ & 1.00 \\
BADL & 1.00 & $1.76(0.41-7.41)$ \\
$\quad$ Independent & $4.69(1.45-15.11)$ & 1.00 \\
$\quad$ Dependent & 1.00 & $1.49(0.66-3.36)$ \\
MMSE & $1.84(0.91-3.70)$ & $0.93(0.85-1.03)$ \\
$\quad$ No alteration & $0.91(0.84-0.98)$ & $1.01(0.95-1.06)$ \\
$\quad$ With alteration & $1.01(0.96-1.05)$ & \\
Years of schooling & & \\
Age &
\end{tabular}

Note: MMSE - Mini Mental State Examination; GDS - Geriatric Depression Scale; BADL - Basic Activity of Daily Living. Source: Authors (2021).

\section{Discussion}

The majority of the evaluated older people presented a pro-inflammatory DII, which was also found in a study carried out with American older people participating in the National Health and Nutrition Examination Survey (Resciniti et al., 2019). Although studies that estimated DII are scarce in Brazil, two studies were found in which the results also pointed to proinflammatory diets. The first concerns a study conducted with 72 patients in the hemodialysis sector, where the mean age of the participants was 74.9 years and $44.4 \%$ of the patients presented a highly inflammatory dietary profile (Pimentel et al., 2016). The second was carried out with 2017 young adults ( 23 to 25 years old) and the results also characterized a proinflammatory diet (Carvalho et al., 2019) .

The prevalences of sarcopenia and frailty syndrome were $17.78 \%$ and $47.41 \%$, respectively. Considering that the sample consisted of older people in outpatient care, these prevalences are close to those found in other studies. In a study performed with 483 individuals aged over 60, attended at two community health centers in China, the prevalence of sarcopenia was $22,3 \%$ for men and 11,7\% for women defined by the initial EWGSOP (Yang et al., 2020) .In another study, carried out with 123 older people in outpatient care in the Netherlands, the prevalence of sarcopenia, according to the EWGSOP criteria, was $25.2 \%$ (Reijnierse et al., 2015) . In Brazil, some studies that used similar metrics have similar results to those found in our study population. In a study carried out with older people registered in a Family Health Unit in the city of Piracicaba,São Paulo, used the Self-Reported Frailty, which indicated that $44.6 \%$ of the participants were frail (Moura et al., 2020).In another study with 820 older people, residing in the rural area of the Municipality of Pelotas, Rio Grande do Sul, to assess frailty, the self-reported instrument was also used, with $43.4 \%$ of the elderly as frail as a result (Lange et al., 2017).

In relation to frailty, a study with the objective of investigating the prevalence of frailty in older people in the community in countries of Latin America and the Caribbean through a systematic review and meta-analysis found a prevalence of $19.6 \%$, with variations from $7.7 \%$ to $42.6 \%$ in the 29 studies reviewed. According to data from the Hellenic Longitudinal Investigation of Aging and Diet (HELIAD), the prevalence of frailty varied from $4.1 \%$ to $30.2 \%$, depending on the definition used (Ntanasi et al., 2018) . Research carried out with older people attended in an outpatient setting showed even higher values. In a study conducted with 120 older people in outpatient care in Canada, for example, the prevalence of frailty varied between 35\% and 50\% depending on the measurement method used (Pritchard et al., 2017) .Another study, carried out with 404 older people seen at a geriatric outpatient clinic in the Netherlands, found a prevalence of $47 \%$ (Kurkcu et al., 2018).

Regarding the association with frailty, the results of the present study showed that older people with a proinflammatory DII are more likely to be frail. The same result was observed in a cohort study carried out with a sample of 4421 
older Americans, demonstrating that a pro-inflammatory diet was associated with a higher incidence of frailty, especially in men (Shivappa et al., 2018) and in a study conducted in South Korea, with a sample of 357 older people, which showed that a pro-inflammatory diet is associated with an increased risk of frailty in older people with an inadequate nutritional status. In addition, in the latter study it was observed that unintentional weight loss, low walking speed, and low handgrip strength were also positively correlated with the most negative DII scores (Kim \& Park, 2018).

A study carried out with a sample of 7182 older Americans participating in the National Health and Nutrition Examination Survey revealed that higher scores in the Dietary Inflammatory Index (DII) were associated with pre-frailty and frailty in the older people (Resciniti et al., 2019). Other study, conducted with 1948 older people from the Seniors-ENRICA cohort, also revealed that a pro-inflammatory diet was associated with frailty in older people (Laclaustra et al., 2020) .

The explanation for this association can be understood by the fact that chronic inflammation plays an important role in the pathogenesis of frailty, since the increase in inflammatory markers may be related to the decline in different regulatory mechanisms, enabling activated defense cells to continue secreting potent catabolic agents long after an aggressive stimulus has been initiated. Chronic exposure to high levels of pro-inflammatory agents can lead to frailty due to the catabolic influence on the muscle and worsening neuroendocrine dysregulation through increased adrenocortical stimulation (Fried et al., 2009) .

Furthermore, with regard to sarcopenia, the present study did not demonstrate a significant association between the most inflammatory DII and the occurrence of this condition. On the other hand, results of a meta-analysis of 14 cross-sectional studies revealed that inflammatory cytokines were positively associated with the risk of sarcopenia in older people (Shokrimashhadi et al., 2021) .It is worth noting that studies seeking an association between DII and sarcopenia are scarce in the literature, which makes it difficult to understand the possible factors responsible for the absence of an association in the current study and reinforces the need for further research, especially with longitudinal designs and larger samples.

The limitations of the study include: determining the sample by convenience; difficulty in standardizing the homemade measures used in the food recall, use of muscle strength cutoff points defined according to the European Consensus and absence of DII for some foods, since the application used to calculate the index originates in the USA and this index has no validation for the Brazilian population.

Regarding the frailty instrument used, it is a screening instrument, whose validation precluded the assessment of the predictive validity of the self-reported instrument for adverse outcomes, including functional decline, rate of hospitalization, and death. However, the subjective assessment of frailty has advantages for being multidimensional, quick to assess, with low cost, in addition to being validated with elderly people in the community and can be applied by different professionals (Lange et al., 2017).

As for the estimation of appendicular skeletal muscle mass, the use of Lee's equation is justified by feasibility of Obtaining weight and height measures in clinical practice, also validated for the Brazilian population. But limiting points are addressed, such as performance impairment may be related to inclusion of healthy subjects, with normal BMI and obesity, leaving aside the overweight classification (Barreto Silva et al., 2021).

The strong points of this work are the fact that this theme has been little explored and the use of internationally validated constructs to assess Fragility Syndrome and Sarcopenia in older people.

\section{Conclusion}

The current study investigated the association between DII and frailty and between DII and sarcopenia in older people in outpatient care. It was found that only frailty was associated with DII, and older people who presented a pro-inflammatory 
DII are more likely to be frail than older people with a less inflammatory DII in the model adjusted for depressive symptoms, cognitive performance, functional capacity, years of schooling, and age.

Older people in outpatient care have illnesses and dependency conditions to be treated and, since they are receiving care in a health service, they are more likely to achieve good results from the treatments provided. Thus, specific interventions to prevent sarcopenia and frailty, or even delay the evolution of the condition by promoting an anti-inflammatory and balanced diet should be encouraged.

Early intervention in the individual's lifestyle, including dietary pattern, should be taken into account in the development of prevention programs for the elderly and also in planning for a successful old age. In order to control the inflammatory profile and prevent the occurrence of these geriatric syndromes. Future studies can implement specific interventions in the feeding of adults and monitor them over the years.

\section{Acknowledgments}

The authors would like to thank the team at the Outpatient Clinic Aparecida de Alfenas, Minas Gerais, Brazil, for their cooperation during data collection.

\section{Funding}

This research did not receive any specific grant from funding agencies in the public, commercial, or not-for-profit sectors.

\section{References}

Barreto Silva, M. I., Menna Barreto, A. P. M., Pontes, K. S. da S., Costa, M. S. da, Rosina, K. T. de C., Souza, E., Bregman, R., Prado, C. M., \& Klein, M. R.S. T. (2021). Accuracy of surrogate methods to estimate skeletal muscle mass in non-dialysis dependent patients with chronic kidney disease and in kidney transplant recipients. Clinical Nutrition (Edinburgh, Scotland), 40(1), 303-312. https://doi.org/10.1016/j.clnu.2020.05.021

Brucki, S. M. D., Nitrin, R., Caramelli, P., Bertolucci, P. H. F., \& Okamoto, I. H. (2003). Suggestions for utilization of the mini-mental state examination in Brazil. Arquivos de Neuro-Psiquiatria, 61(3 B), 777-781. https://doi.org/10.1590/s0004-282x2003000500014

Carvalho, C. A., Silva, A. A. M., Assunção, M. C. F., Fonseca, P. C. A., Barbieri, M. A., Bettiol, H., Shivappa, N., \& Hébert, J. R. (2019). The dietary inflammatory index and insulin resistance or metabolic syndrome in young adults. Nutrition (Burbank, Los Angeles County, Calif.), 58, 187-193. https://doi.org/10.1016/j.nut.2018.07.014

Cruz-Jentoft, A. J., Bahat, G., Bauer, J., Boirie, Y., Bruyère, O., Cederholm, T., Cooper, C., Landi, F., Rolland, Y., Sayer, A. A., Schneider, S. M., Sieber, C. C., Topinkova, E., Vandewoude, M., Visser, M., Zamboni, M., Bautmans, I., Baeyens, J. P., Cesari, M., ... Schols, J. (2019). Sarcopenia: Revised European consensus on definition and diagnosis. Age and Ageing, 48(1), 16-31. https://doi.org/10.1093/ageing/afy169

Delmonico, M. J., Harris, T. B., Lee, J. S., Visser, M., Nevitt, M., Kritchevsky, S. B., Tylavsky, F. A., \& Newman, A. B. (2007). Alternative definitions of sarcopenia, lower extremity performance, and functional impairment with aging in older men and women. Journal of the American Geriatrics Society, 55(5), 769-774. https://doi.org/10.1111/j.1532-5415.2007.01140.x

Folstein, M. F., Folstein, S. E., \& McHugh, P. R. (1975). "Mini-mental state": A practical method for grading the cognitive state of patients for the clinician. Journal of Psychiatric Research, 12(3), 189-198. https://doi.org/https://doi.org/10.1016/0022-3956(75)90026-6

Fried, L. P., Xue, Q. L., Cappola, A. R., Ferrucci, L., Chaves, P., Varadhan, R., Guralnik, J. M., Leng, S. X., Semba, R. D., Walston, J. D., Blaum, C. S., \& Bandeen-Roche, K. (2009). Nonlinear multisystem physiological dysregulation associated with frailty in older women: Implications for etiology and treatment. Journals of Gerontology - Series A Biological Sciences and Medical Sciences, 64(10), 1049-1057. https://doi.org/10.1093/gerona/glp076

Katz, S., Ford, A. B., Moskowitz, R. W., Jackson, B. A., \& Jaffe, M. W. (1963). Studies of Illness in the Aged: The Index of ADL: A Standardized Measure of Biological and Psychosocial Function. JAMA, 185(12), 914-919. https://doi.org/10.1001/jama.1963.03060120024016

Kim, D., \& Park, Y. (2018). Association between the dietary inflammatory index and risk of frailty in older individuals with poor nutritional status. Nutrients, 10(10). https://doi.org/10.3390/nu10101363

Kurkcu, M., Meijer, R. I., Lonterman, S., Muller, M., \& de van der Schueren, M. A. E. (2018). The association between nutritional status and frailty characteristics among geriatric outpatients. Clinical Nutrition ESPEN, 23, 112-116. https://doi.org/https://doi.org/10.1016/j.clnesp.2017.11.006

Laclaustra, M., Rodriguez-Artalejo, F., Guallar-Castillon, P., Banegas, J. R., Graciani, A., Garcia-Esquinas, E., \& Lopez-Garcia, E. (2020). The inflammatory potential of diet is related to incident frailty and slow walking in older adults. Clinical Nutrition, 39(1), 185-191. https://doi.org/10.1016/j.clnu.2019.01.013 
Lange, C., Nunes, D. P., \& Pastore, C. A. (2017). Artigo Original Fragilidade em idosos da zona rural : proposta de algoritmo de cuidados Frailty in rural older adults : development of a care algorithm. 30(5), 520-530.

Lawton, M. P., \& Brody, E. M. (1969). Assessment of older people: self-maintaining and instrumental activities of daily living. The Gerontologist, 9(3), 179186.

Lee, R. C., Wang, Z., Heo, M., Ross, R., Janssen, I., \& Heymsfield, S. B. (2000). Total-body skeletal muscle mass: development and cross-validation of anthropometric prediction models. The American Journal of Clinical Nutrition, 72(3), 796-803. https://doi.org/10.1093/ajcn/72.3.796

Lipschitz, D. . (1994). Screening for nutritional status in the elderly. Prim. Care, 21, 55-67.

Moura, K., Machado de Jesus, I. T., Angelini dos Santos Orlandi, A., \& Silvana Zazzetta, M. (2020). Fragilidade E Suporte Social De Idosos Em Região Vulnerável: Uma Abordagem Em Uma Unidade De Saúde Da Família. Revista de Atenção à Saúde, 18(63), 65-73. https://doi.org/10.13037/ras.vol18n63.6342

Newman, A. B., Kupelian, V., Visser, M., Simonsick, E., Goodpaster, B., Nevitt, M., Kritchevsky, S. B., Tylavsky, F. A., Rubin, S. M., \& Harris, T. B. (2003). Sarcopenia: Alternative Definitions and Associations with Lower Extremity Function. Journal of the American Geriatrics Society, 51(11), 1602-1609. https://doi.org/10.1046/j.1532-5415.2003.51534.x

Ntanasi, E., Yannakoulia, M., Mourtzi, N., Vlachos, G. S., Kosmidis, M. H., Anastasiou, C. A., Dardiotis, E., Hadjigeorgiou, G., Megalou, M., Sakka, P., \& Scarmeas, N. (2018). Prevalence and Risk Factors of Frailty in a Community-Dwelling Population: The HELIAD Study. Journal of Aging and Health, 32(12), 14-24. https://doi.org/10.1177/0898264318801735

Nunes, D. P., Duarte, Y. A. de O., Santos, J. L. F., \& Lebrão, M. L. (2015). Screening for frailty in older adults using a self-reported instrument. Revista de Saude Publica, 49(1). https://doi.org/10.1590/S0034-8910.2015049005516

Pimentel, C. K. dos S., Santos, C. M. dos, \& Luz Neto, L. M. da. (2016). Características nutricionais e fator inflamatório das dietas usadas por pacientes em terapia renal substitutiva. 31(3), 208-220.

Polit, D., \& Beck, C. (2011). Fundamento de Pesquisa em Enfermagem : Avaliação de evidências para a prática de enfermagem (7ª). Artmed.

Pritchard, J. M., Kennedy, C. C., Karampatos, S., Ioannidis, G., Misiaszek, B., Marr, S., Patterson, C., Woo, T., \& Papaioannou, A. (2017). Measuring frailty in clinical practice: A comparison of physical frailty assessment methods in a geriatric out-patient clinic. BMC Geriatrics, $17(1)$, 1-8. https://doi.org/10.1186/s12877-017-0623-0

Reijnierse, E. M., Trappenburg, M. C., Leter, M. J., Blauw, G. J., Sipilä, S., Sillanpää, E., Narici, M. V, Hogrel, J.-Y., Butler-Browne, G., McPhee, J. S., Gapeyeva, H., Pääsuke, M., de van der Schueren, M. A. E., Meskers, C. G. M., \& Maier, A. B. (2015). The Impact of Different Diagnostic Criteria on the Prevalence of Sarcopenia in Healthy Elderly Participants and Geriatric Outpatients. Gerontology, 61(6), 491-496. https://doi.org/10.1159/000377699

Reinagel M. (2007). The Inflammation - Free Diet Plan. McGraw - Hill Education.

Resciniti, N. V, Lohman, M. C., Wirth, M. D., Shivappa, N., \& Hebert, J. R. (2019). Dietary Inflammatory Index, Pre-Frailty and Frailty Among Older US Adults: Evidence from the National Health and Nutrition Examination Survey, 2007-2014. The Journal of Nutrition, Health \& Aging, 23(4), 323-329. https://doi.org/10.1007/s12603-019-1164-3

Rossi, P. G., Carnavale, B. F., Farche, A. C. S., Ansai, J. H., de Andrade, L. P., \& Takahashi, A. C. de M. (2021). Effects of physical exercise on the cognition of older adults with frailty syndrome: A systematic review and meta-analysis of randomized trials. Archives of Gerontology and Geriatrics, 93, 104322. https://doi.org/10.1016/j.archger.2020.104322

Shivappa, N., Stubbs, B., Hébert, J. R., Cesari, M., Schofield, P., Soysal, P., Maggi, S., \& Veronese, N. (2018). The Relationship Between the Dietary Inflammatory Index and Incident Frailty: A Longitudinal Cohort Study. Journal of the American Medical Directors Association, 19(1), 77-82. https://doi.org/10.1016/j.jamda.2017.08.006

Shokri-mashhadi, N., Moradi, S., Heidari, Z., \& Saadat, S. (2021). Association of circulating C-reactive protein and high-sensitivity C-reactive protein with components of sarcopenia: A systematic review and meta-analysis of observational studies. Experimental Gerontology, 150(July 2020), 111330. https://doi.org/10.1016/j.exger.2021.111330

Teskey, G., Bundalovic-Torma, C., \& Bowdish, D. (2019). Age-associated inflammation alters the aging trajectory. Biochemist, 41(1), 22-25. https://doi.org/10.1042/bio04101022

Vadell, A. K. E., Bärebring, L., Hulander, E., Gjertsson, I., Lindqvist, H. M., \& Winkvist, A. (2020). Anti-inflammatory Diet In Rheumatoid Arthritis (ADIRA) - a randomized, controlled crossover trial indicating effects on disease activity. The American Journal of Clinical Nutrition, 111(6), 1203-1213. https://doi.org/10.1093/ajcn/nqaa019

Yang, L., Yao, X., Shen, J., Sun, G., Sun, Q., Tian, X., Li, X., Li, X., Ye, L., Zhang, Z., Dai, J., \& Xiao, H. (2020). Comparison of revised EWGSOP criteria and four other diagnostic criteria of sarcopenia in Chinese community-dwelling elderly residents. Experimental Gerontology, $130,110798$. https://doi.org/10.1016/j.exger.2019.110798

Yesavage, J. A., \& Sheikh, J. I. (1986). 9/Geriatric Depression Scale (GDS). Clinical Gerontologist, 5(1-2), 165-173. https://doi.org/10.1300/J018v05n01_09 